\title{
Research on Accounting Ethics Education
}

\author{
Jingyi Zhao \\ School of Accounting \\ Jilin Business and Technology College \\ Changchun, Jilin, China (PRC)
}

\begin{abstract}
This article is based on the relevant meanings of accounting ethics and accounting ethics education, takes the current situation of accounting ethics education of college students as the starting point, combining with the current situation of crisis of integrity in accounting and the absence of accounting ethics education. Finally, more scientific, more innovative and more executable advice on the development of accounting ethics is proposed.
\end{abstract}

Keywords—accounting ethics; accounting ethics education

\section{INTRODUCTION}

With the development of the market economy, the crisis of integrity and accounting information have become so distorted that we gradually realize that some accounting actors have lost their due ethics, which fully embodies the current situation of accounting ethics in China and the deterioration of education, and the research on accounting ethics is not enough.

\section{THE DEFINITION OF ACCOUNTING ETHICS AND ACCOUNTING ETHICS EDUCATION}

Ethics is based on "moral phenomenon", which emphasizes on the general specification of social moral phenomenon, aimed at analyzing on social individual, individual and social, individual and environment, and which reveals its development rules. Accounting ethics study the phenomenon of accounting professional ethics, which include Ethics of accounting staff relations, Ethics of accounting work relationship, ethics of the relationship of accounting organization, Accounting industry ethics and other aspects. We believe that accounting ethics is primarily concerned with the ethical relationship that analysis of accounting work environment, its core is to the philosophy of ethics in the accounting environment related analysis, to further reveal the internal law of development of research work.

Accounting ethics education, which refers to a specific group that the rule of the ruling class, the purpose is to develop and establish the accounting personnel and accounting ethics fashion that meets his/her needs, according to the certain social ethics and accounting ethics system, purposeful, planned and organized to relevant personnel for the system of moral influence. It is an important activity that

Jilin Provincial Association of Higher Education scientific research project JGJX2016D137 the specific accounting ethic demands and the general moral requirements of society translate into the ethical spirit and moral quality of the accounting behavior. Therefore, through the accounting ethics education make accounting behavior main body good internal quality and ideal personality, make the accounting ethical obligations consciously and adjustment of accounting behavior, finally set up good social accounting ethics important way and means of fashion.

\section{ACCOUNTING ETHICS EDUCATION DEFICIENCY STATUS ANALYSIS}

As the subject of education, many universities and professional teachers can recognize the importance of accounting professional ethics education in the development of accounting industry, but the reality is that the lack of professional moral education resources, the course is too theoretical, there is too theoretical out of reality. The education reality that this supply and demand is disjointed seriously cannot achieve your goal of great help for professional college students, and has not received enough attention that from universities. At present, the professional education of accounting ethics education in China is almost blank, and the scattered accounting professional moral knowledge can't systematically affect student's professional value.

\section{The Way to Solve the Problem of Accounting ETHICS EDUCATION}

The premise of the solution is Confirm the status of education of accounting ethics, relevant authorities should make the most authoritative definition of the position of education of accounting ethics by means of laws, regulations and guidance.

\section{A. To Speed up the Accounting Ethics Constructive Materials}

In terms of accounting ethics education itself, to solve the fundamental problem of the accounting ethics construction must first have a combined with its national conditions, combining the characteristics of its own economic solid both theory and practice of accounting ethics teaching material, can be directly from the professional values education of college students. Accounting ethics teaching materials should include the basic theory of accounting professional ethics, accounting ethics case analysis, to solve the actual problem, for through to the accounting issues related to 
rational analysis, establish and improve accounting personnel's professional value as the final goal.

\section{B. Innovative Accounting Ethics Education Method}

In the case of students with basic accounting knowledge, the author makes a bold assumption that the first semester of the fourth year of college is the accounting ethics teaching period. In the process, it is possible to carry out a discussion on the ethical case of the central topic of accounting ethics, and then we can let accountant actual operator give the student to carry on the explanation and analysis. To make students learn to solve relevant ethical choice problems, have basic accounting ethics presumption ability, to realize the positive effect of accounting ethics on accounting professionalism. At the same time, we can also establish an open accounting ethics teaching case library in the process of implementation, which can be helpful to the relevant people to solve relevant problems. Accounting professional education curriculum setting should concentrate on the content of the moral qualities and moral reasoning ability of education and training, which should strengthen the education of accounting ethics, and pay attention to the shaping of accounting professional values, as to the final is to separate accounting ethics into class, or to embed the ethical content in the professional curriculum system that still needs further research and exploration. Accounting ethics is about the accounting principle, the spirit of science, is the most general to solve the problem of accounting sincerity is the most common fundamental ideas. Accounting ethics is the accounting philosophy used to explain accounting behavior.

\section{Strengthen Teacher's Training on Accounting Ethics}

The premise of solving the problem of education of accounting ethics is to strengthen teacher training. At present, the current situation of accounting professional teachers in China mainly focuses on the degree of education, which usually requires a master's degree and doctorate. However, people with obvious academic qualifications often lack the experience of accounting practice; the knowledge of accounting is taught about the existence of theory and reality. The professional education and the accounting practice are seriously out of touch, and the theory education is not fully matched with the actual ethical demand point, which will bring considerable obstacles to the concrete implementation of accounting ethics education. on the other hand, Intermediate accountants, senior accountant engaged in the professional education is also considerable, but this part of the professional teachers and hard to avoid can be in the actual working experiences of choice, avoid to the classroom teaching process, the shaping of students' professional values is also a disadvantage. Therefore, training teachers, training for the recognition of accounting ethics and education status, training their understanding of accounting ethics knowledge, which can help them promote accounting ethics of the teaching job. Finally, a teacher can be a real teacher.

\section{CONCLUSION}

To sum up, solve the problem of accounting ethics education is from status confirmation, the curriculum, teaching material construction and innovative education system, aimed at giving students in all aspects to instill integrity concept, improve the students' professional judgment and professional is discrimination. Ultimately, for the enterprise to provide qualified accounting talents for the society, but also for the formation of healthy atmosphere of accounting profession determined the purpose of a solid foundation.

\section{REFERENCES}

[1] Y.F. Ma. A Study on the Problem of Dishonesty of Chinese Accounting Practitioners Based on Accounting Ethics (In Chinese), (MS., Lanzhou university, China 2009), p.18-20.

[2] Y.J. Ma. Friends of Accounting (In Chinese), (2011) No.11, p.4-8

[3] M. Li. Accounting Communications (In Chinese), (2010) No.7, p.3-7.

[4] D. Li. Liu. Investigation and Reflection (In Chinese), (2010) No.2, p.185.

[5] L.L. Zhang. Hunan Social Science (In Chinese), (2008) No.6, p.204206. 